\title{
Formation of Alternative Reality IN TOTALITARIAN SOCIETY: MYTHOLOGIZATION of Chornobyl Catastrophe in 1986
}

\section{FORMOWANIE ALTERNATYWNEJ RZECZYWISTOŚCI W SPOEECZEŃSTWIE TOTALITARNYM: MITOLOGIZACJA CZARNOBYLSKIEJ KATASTROFY W 1986 ROKU}

\begin{abstract}
The Soviet Union authorities created such a political system according to which invention of myths, convenient for the authority was quite a simple task. Any „inconvenient" event was considered within „secret” stamp, the truth was either just hidden or (if publicity was inevitable) was transformed through mythologization - i.e. certain alternative soviet reality was created. The Chornobyl catastrophe which took place on April 26 $6^{\text {th }}$ in 1986 can be considered one of such "inconvenient” events for USSR.

\section{Purpose}

The purpose of the article is to reveal practical technology of alternative reality formation in soviet society dased on the example Chornobyl catastrophe (1986) mythologization.

\section{Material and methods}

During the research analyses and generalization of archive sources which were declassified by the Security Service of Ukraine have been performed. Also, analyses of scientific sources and documents, overview of soviet mass media related to the topic has been carried out.

\section{Conclusions}

All elements of alternative reality formation (mythologization), commonly used by KGB (Committee for State Security of the Soviet Union) namely truth secrecy; docu-
\end{abstract}


ments and material evidence destruction; intimidation; true information sources blocking; alternative "truth” formation; spreading such „truth” in mass media - all of them were implied in full. But the detection of the myth within historical time period came very quickly. Myth proved to be fragile - the occurrence of chemical reactions couldn't be subordinated to the soviet power prescripts, they couldn't be intimidated with KGB methods, however, the catastrophe consequences seemed too vivid for the full suppression. Main reason of failure in formation of soviet myth about harmlessness of radiation was international publicity.

\section{STRESZCZENIE}

Władze Związku Radzieckiego stworzyły system polityczny, w którym tworzenie mitów, wygodnych dla władzy, było dość prostym zadaniem. Przy każdym „niewygodnym" wydarzeniu prawda została albo po prostu ukryta, albo mitologizowana. $\mathrm{W}$ ten sposób powstała alternatywna sowiecka rzeczywistość. Czarnobylską katastrofę, która wydarzyła się 26 kwietnia 1986 r., można uznać za jedno z wielu mitologizowanych wydarzeń w ZSRR.

Cel

Celem artykułu jest ujawnienie praktycznej technologii formowania rzeczywistości alternatywnej w społeczeństwie sowieckim na przykładzie mitologizacji katastrofy w Czarnobylu (1986).

\section{Materiał i metody}

Przeprowadzono analizy i uogólnienie źródeł archiwalnych, które zostały odtajnione przez Służbę Bezpieczeństwa Ukrainy. Przeprowadzono również analizy źródeł i dokumentów naukowych oraz przegląd sowieckich środków masowego przekazu związanych z tematem.

\section{Wnioski}

Wszelkie dostępne środki konstruowania rzeczywistości alternatywnej (mitologizacji), praktykowane przez KGB (Komitet Bezpieczeństwa Państwowego Związku Radzieckiego) - zatajanie prawdy; niszczenie dokumentów i dowodów rzeczowych; zastraszanie; blokowanie dostępu do źródeł wiarygodnej informacji; tworzenie "prawdy" alternatywnej; rozpowszechnianie jej w mediach - zostały przez władze radzieckie zastosowane. Ale mit okazał się kruchy - przebiegu reakcji chemicznych nie można było podporządkować wytycznym władz radzieckich i zastraszyć metodami KGB, a skutki awarii były zbyt oczywiste, by je całkowicie pominąć milczeniem. Główną przyczyną niepowodzenia w budowaniu radzieckiego mitu o nieszkodliwości promieniowania był rozgłos międzynarodowy.

Keywords: alternative reality, myhtologization, Chornobyl Nuclear Power Station, soviet mass media, KGB (Committee for State Security of the Soviet Union) 
SŁOWA KLUCzOWE: rzeczywistość alternatywna, mitologizacja, Czarnobylska Elektrownia Jąrowa, radzieckie środki masowego przekazu, KGB (Komitet Bezpieczeństwa Państwowego Związku Radzieckiego)

\section{WPROWADZENIE: WYPADEK W CZARNOBYLU - JEDEN Z WIELU W ZSRR}

14 maja 1986 roku, trzy tygodnie po katastrofie, generalny sekretarz Komitetu Centralnego Komunistycznej Partii Związku Radzieckiego Michaił Gorbaczow oświadczył, że po raz pierwszy zetknięto się z tak wielką siłą, jaką jest energia jądrowa, która wyszła spod kontroli [Chornobyl': vystupleniye M.S. Gorbacheva..., 1986]. W zdaniu tym zawiera się twierdzenie, że radziecka władza po raz pierwszy nie była w stanie kontrolować działania energii jądrowej. Faktycznie było to przyznanie się, że inne radzieckie próby atomowe były zaplanowane. Innymi słowy, oznacza to, że ofiary w ludziach w poprzednich około 1000 prób jądrowych [Sekretnyy front..., 2017], które były przeprowadzone od 1949 do 1986 roku, także były „zaplanowane”. Na podstawie relacji świadków największe z tych prób to następujące wydarzenia.

29 sierpnia 1949 roku na poligonie atomowym w Semipałatinsku (wschodni Kazachstan) władza radziecka wykonała próbę $\mathrm{z}$ bombą atomową RDS-1. W jej rezultacie 21 tysięcy mieszkańców zostało poddanych intensywnemu napromieniowaniu, ponieważ świadomie pozostawiono ich w strefie radioaktywnej, nie uprzedzając o niebezpieczeństwie. Celem eksperymentu było sprawdzenie, czy ludność może przeżyć, jeśli władza zdecyduje się rozpocząć wojnę jądrową w pełnym wymiarze. W ciągu następnych 40 lat na poligonie atomowym w Semipałatyńsku przeprowadzono jeszcze 456 prób jądrowych [Sekretnyy front... 2017, 8:55-16:10 min]. Ich rezultatem były udokumentowane w tej miejscowości liczne mutacje. Zostały one zaprezentowane w Muzeum Anatomicznym Państwowego Medycznego Uniwersytetu miasta Semej (Semipałatinsk) - Muzeum Embrionów Mutantów [Miller 2016].

14 września 1954 roku na poligonie w Tocku (niedaleko Orenburga) odbyło się tajne szkolenie „Snieżok”, w czasie którego zrzucono bombę o sile większej niż obydwie bomby zrzucone na Hiroszimę i Nagasaki. W operacji 
specjalnej brało udział 45 tysięcy żołnierzy, którzy symulowali prawdziwą walkę. Głównym jej celem było sprawdzenie niszczycielskiej siły broni atomowej na ludziach oraz sprzęcie. Sprawdzano, czy radziecka armia będzie potrafiła atakować w warunkach wojny jądrowej. Po tym eksperymencie zaczęły pojawiać się edukacyjne materiały informacyjne o zasadach działania w czasie wybuchu [Sekretnyy front..., 2017, 16:11-19:16 min; Tissen 2005; Repetitsiya Apokalipsisa...].

29 września 1957 roku w zamkniętym mieście Czelabińsk-40 (od 1994 roku Ozersk) w fabryce „Majak”, która produkuje bomby plutonowe, nastąpił wybuch radioaktywnych odpadów. Ta awaria nosi nazwę „Kysztymska”. $\mathrm{W}$ rezultacie wybuchu terytorium $23000 \mathrm{~km}^{2}$ ogłoszono strefą radioaktywnego skażenia [Sekretnyy front..., 2017, 20:13-24:29 min; The wasteful truth... 1980; Tolstikov, 2007].

30 października 1961 roku na Archipelagu Nowa Ziemia zdetonowano największą w historii bombę wodorową [Tsar Bomba 2014; Ispytaniye Tsar' - bomby, 2012].

W wymienionych wyżej oraz wielu innych próbach jądrowych przeprowadzono eksperymenty dotyczące wpływu różnych dawek radiacji na ludzi, zwierzęta i środowisko naturalne. Wszystkie dane były utajniane i przekazywane bezpośrednio do Moskwy. Żołnierzy oraz lekarzy zobowiązano do nieujawniania informacji. Ocenę przeprowadzanych przez władzę radziecką eksperymentów można podsumować słowami politologa Ołeha Soskina, który stwierdził: „Eksperymenty, które tu były przeprowadzane na ludziach niczym nie odróżniały się od eksperymentów w faszystowskich obozach koncentracyjnych" [Sekretnyy front..., 2017]. Natomiast rosyjska obrończyni praw człowieka oraz polityczna emigrantka Nadezhda Kutepova stwierdziła, że Rosja kontynuuje badania oraz obserwacje mutacji na kolejnych pokoleniach ludzi [Sekretnyy front..., 2017, 44:31-46:47 $\mathrm{min}]$.

Odnośnie do mutacji w Semipałatyńsku oficjalnie stwierdzono, że „(..) w żadnym przypadku bezpośredni związek z poligonem nie był potwierdzony, zaś etiologia wielu anomalii nieznana jest nauce... Niemniej nikt nie zaprzecza, że intensyfikacja wrodzonych anomalii przypadła właśnie na okres aktywnych prób jądrowych" [Miller 2016]. 


\section{UTAJNIANIE INFORMACJI}

Kierownictwo Związku Radzieckiego stworzyło taki system polityczny, w którym produkowanie wygodnych dla władzy mitów i stereotypów nie nastręczało szczególnej trudności. Wszelka niewygodna sytuacja otrzymywała klauzulę „ściśle tajne”. Prawda była albo ukrywana, albo (jeśli rezonans był nie do uniknięcia) poddawana mitologicznej transformacji. Jednym z takich niewygodnych dla ZSRR wydarzeń była awaria czwartego bloku Czarnobylskiej Elektrowni Jądrowej, która wydarzyła się 26 kwietnia 1986 roku.

Czarnobylska katastrofa uważana jest za pierwszy sprawdzian polityki „głasnosti”, którą Michaił Gorbaczow ogłosił na zjeździe KPZR w lutym 1986 roku [Zanuda, 2016a]. Sprawdzianem, którego system ZSRR nie zdał. Natomiast zgodnie z tradycją, charakterystyczną dla "niewygodnych” wydarzeń, epizod ten został zmitologizowany.

Analiza odtajnionych dokumentów oraz wnioski komisji eksperckich jednoznacznie pokazują, że wybuch nastąpił w wyniku poważnych niedociągnięć podczas budowy, eksploatacji oraz nieprzestrzegania zasad bezpieczeństwa pracy reaktora czwartego bloku elektrowni. Awaria ujawniła niedoskonałość systemu energetyki jądrowej ZSRR, do czego władza radziecka nie mogła się przyznać. Dlatego odwołała się do tradycyjnej dla ZSRR strategii tworzenia alternatywnej rzeczywistości, w której na początku zaprzeczano samemu faktowi awarii, a następnie jej konsekwencjom.

Od momentu awarii część pierwotnych i najistotniejszych danych o wydarzeniach w Czarnobylskiej Elektrowni Jądrowej była opatrzona klauzulą „ściśle tajne”. Utajnione były przyczyny awarii, dane o: charakterze oraz rozmiarach zniszczeń, składzie wyemitowanej do powietrza substancji, skażeniu radioaktywnym, dane dotyczące napromieniowania personelu, który obsługiwał i remontował blok oraz tych, którzy likwidowali skutki, ogólne dane o zachorowaniach, jak również informacja o nowych efektywnych środkach i metodach dezaktywacji itp. Cały spis, datowany na 8 lipca 1986 roku, zawierał 26 kategorii tajnych danych [Perechen' svedeniy..., 1986; Zdjęcie 1]. Zniszczeniu uległa wielka ilość dokumentów o pracy przy likwidacji i skutkach awarii. Były to na przykład listy przejazdowe (dokumenty, które potwierdzały ewidencję czasu pracy kierowców), które po wyjeździe ze strefy Czarnobylskiej Elektrowni Jądrowej były palone, a dokumenty o udziale żołnierzy „za- 
ginęly” [Zanuda 2016b] itp. Przez takie „okoliczności” później znaczna część osób nie mogła otrzymać oficjalnego statusu likwidatorów awarii.

Zdjęcie 1.

Lista kategorii tajnych danych związanych $\mathrm{z}$ wypadkiem w bloku nr 4 elektrowni jądrowej w Czarnobylu. 07.08.1986, KGB ZSRR

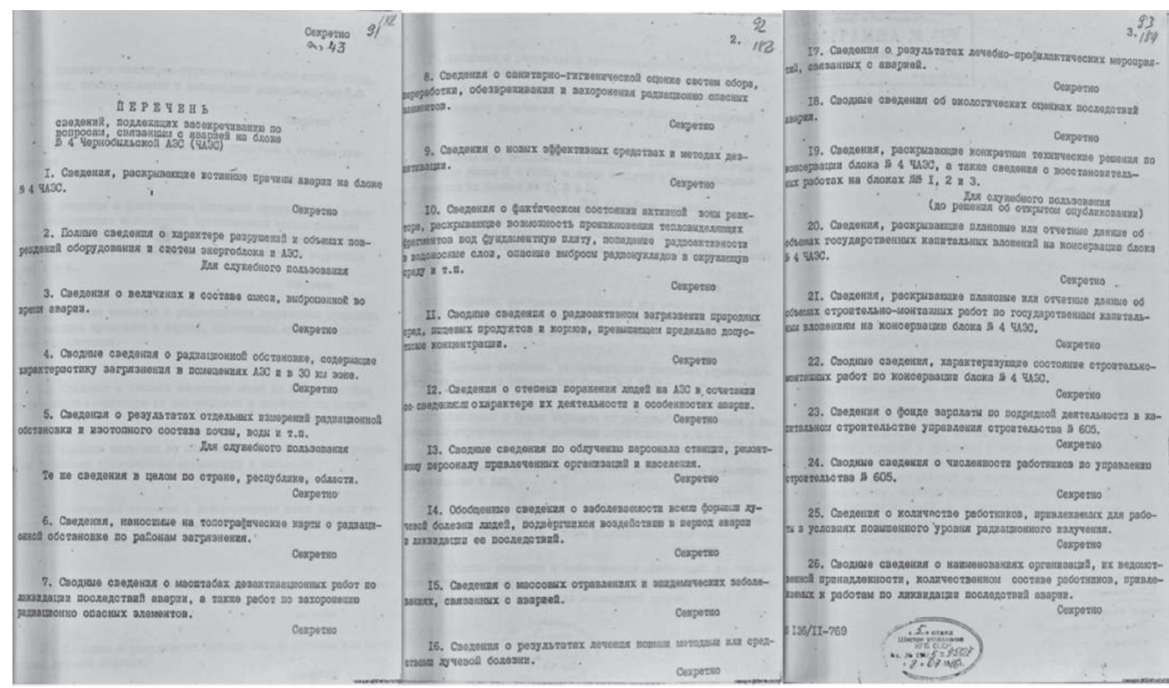

Źródło: [Perechen’ svedeniy..., 1986]

Po analizie odtajnionych dokumentów KGB ZSRR staje się oczywiste, że ratowanie ludzi nie było priorytetem. Najważniejszą kwestią dla ówczesnej władzy było niedopuszczenie do rozpowszechnienia informacji o awarii [Spravka o radiatsionnoy obstanovke..., 1986; Informatsionnoye soobshcheniye..., 1986].

$\mathrm{Na}$ obywatelach ZSRR metody wpływu były wypracowane przez lata. Wśród nich zastraszanie, $\mathrm{w}$ tym poprzez preparowanie kompromitujących dokumentów, wyłączanie z szeregu członków partii, zwolnienia oraz wszczynanie spraw karnych. Praktycznie we wszystkich dokumentach KGB widać cyniczny stosunek do ludzkiego życia. Na przykład w dokumentach z miejsc ewakuacji z 8 maja 1986 roku w tym samym akapicie znajduje się zapis o zwolnieniu z pracy jako formy ukarania oraz konstatuje się fakt znacznej ilości hospitalizacji tych, którzy wykonywali swój służbowy obowiązek. Za 
odmowę wyjechania na miejsce wydarzenia zwolniono pięciu pracowników z organów Urzędu Spraw Wewnętrznych z obwodu kijowskiego. Hospitalizowano 16 pracowników USW miasta Kijów oraz 289 pracowników USW z obwodu kijowskiego. Łącznie 305 osób, z których 20 wysłano do Moskwy [Spravka ob informatsii iz mest evakuatsii..., 1986, Arkusz tomu 137, Strona dokumentu 2]. Tutaj należy zaznaczyć, że wysłanie chorego do Moskwy oznaczało szczególnie ciężki stan jego zdrowia.

Upowszechnianie jakiejkolwiek informacji o awarii Czarnobylskiej Elektrowni Jądrowej organy KGB ZSRR uznawały za krytykę radzieckiej rzeczywistości, co podlegało sankcjom prawnym na podstawie art. 62 Kodeksu Karnego ZSRR „Antyradziecka agitacja i propaganda”. Sankcje na podstawie tego artykułu, na przykład w sytuacji, gdy była to pierwsza sprawa karna, przewidywały pozbawienie wolności na okres od 6 miesięcy do 7 lat z zesłaniem na okres do 5 lat albo zesłanie na okres od 2 do 5 lat [Stattya 62 KK USSR..., 1961].

\section{RADZIECKIE MEDIA JAKO ŚRODEK MITOLOGIZACJI}

Rano 26 kwietnia 1986 roku na odzieży pracowników Forsmark Nuclear Power Plant (Forsmark, Szwecja) system bezpieczeństwa wykrył silnie podniesiony wskaźnik radiacji. Kontrola wykryła, że skażenie nie jest powiązane z pracą tej elektrowni jądrowej. W wyniku analizy danych meteorologicznych stało się jasne, że źródło zagrożenia znajduje się na południowym wschodzie [Chornobyl haunts engineer..., 1996]. Wysyłane noty dyplomatyczne do ZSSR nie przyniosły żadnych rezultatów aż do momentu, gdy Szwecja zagroziła, że zwróci się z oficjalnym zapytaniem do International Atomic Energy Agency (IAEA) [25 years after Chernobyl..., 2011].

Należy podkreślić, że zatajanie faktu awarii przez władzę radziecką było przestępstwem. Z relacji Walentyny Szewczenko (w latach 1984-1990 była przewodniczącą prezydium Rady Najwyższej Ukraińskiej SRR) wiemy, że Czarnobylska Elektrownia Jądrowa była bezpośrednio podporządkowana Moskwie, a nie kierownictwu ukraińskiej SRR, dlatego o awarii najpierw dowiedziano się w Moskwie [Shevchenko, 2011]. O niebezpieczeństwie ludność nie została poinformowana. Nie udzielano żadnych rekomendacji odnośnie do tego, jak zmniejszyć wpływ radioaktywnego promieniowania. Ewakuację ludności rozpoczęto 27 kwietnia 1986 roku po południu. 
Dopiero 28 kwietnia 1986 roku w telewizji ZSRR wyemitowano pierwszą oficjalną informację, która trwała dokładnie 14 sekund i jednocześnie przekonywała, że wszystko jest pod kontrolą: „W Czarnobylskiej Elektrowni Jądrowej wydarzyła się awaria, został uszkodzony jeden z reaktorów, trwają działania zmierzające do likwidacji skutków awarii. Tym, którzy ucierpieli, została udzielona pomoc. Została stworzona komisja państwowa" [Soobshcheniye programmy „Vremya”..., 1986]. Następnego dnia ogłoszenie to w dosłownym brzmieniu zostało przedrukowane w większości ukraińskich gazet na trzeciej lub czwartej stronie, w tym na przykład pod wynikami zmagań sportowych [Zdjęcie 2].

Zdjęcie 2.

„Gazeta Robotnicza” 29 kwietnia 1986 roku

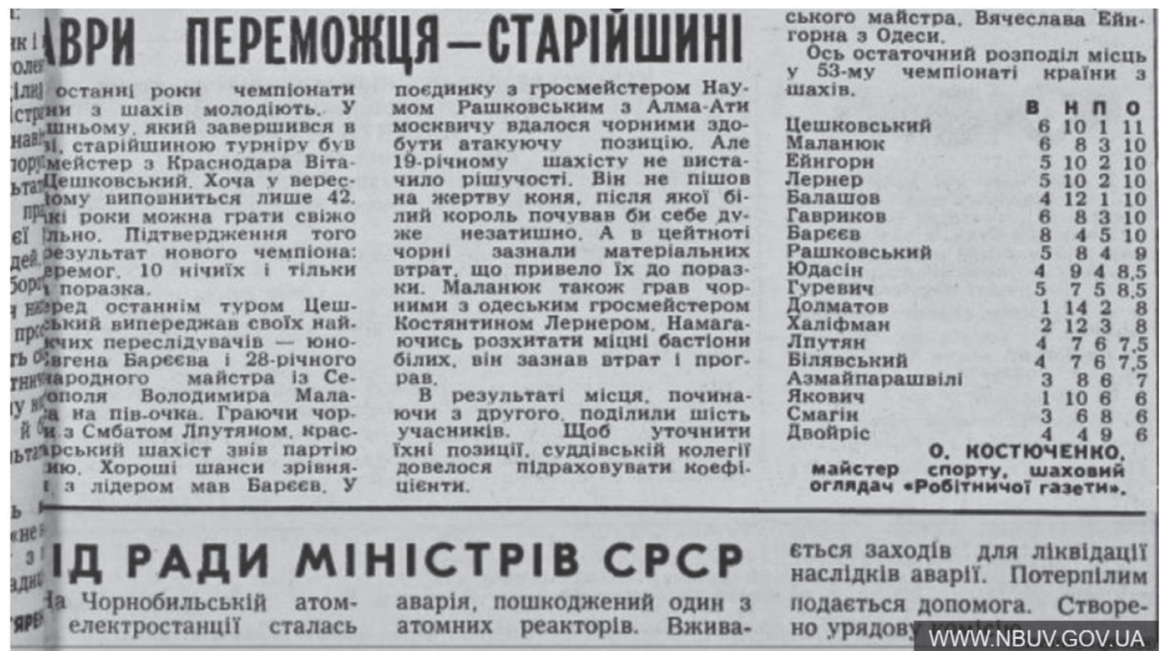

Źródło: [Zanuda, 2016a]

Pełen pogardy stosunek do ludności uwypukliła organizacja pierwszomajowego pochodu w Kijowie. Z relacji Walentyny Szewczenko wiemy, że w 1986 roku kierownictwo ukraińskiej SRR „dostało wskazówkę z Moskwy, iż nie ma żadnej potrzeby przekładać uroczystość... dostaliśmy telegram z Moskwy, w którym wymagano od nas, by nie siać paniki” [Shevchenko, 2011]. Walentyn Zghurskyj (w latach 1979-1990 był przewodniczącym Miej- 
skiego Komitetu Wykonawczego w Kijowie oraz przewodniczącym Rady Kierowników Stolic Republik Radzieckich, Moskwy i Leningradu) tak mówił o pierwszomajowym pochodzie w 1986 roku: Gorbaczow powiedział Szczerbickiemu (w latach 1972-1989 był pierwszym sekretarzem KC KPU) „Odwołasz - zniszczę cię" [Zghurskyi, 2013]. Dlatego gdy w zagranicznych mediach dużo mówiono o zagrożeniu życia, w Kijowie odbywał się marsz z okazji 1 maja, czyli Dnia Międzynarodowej Solidarności Robotników.

Później media radzieckie zaczęły przekazywać skąpe informacje o działaniach mających na celu ochronę przed skutkami awarii, głównym wśród nich był minister ochrony zdrowia USRR. A.J. Romanenko wymienił sprzątanie kurzu. Stwierdził również, że poziom radiacji nie jest niebezpieczny dla zdrowia ludności [Zdjęcie 3]. Wszystko to pomimo faktu, iż prawdziwy poziom skażenia kierownictwo znało z codziennych doniesień [Wykres 4].

Zdjęcie 3.

Gazeta „Prawda Ukrainy”, 9 maja 1986 roku

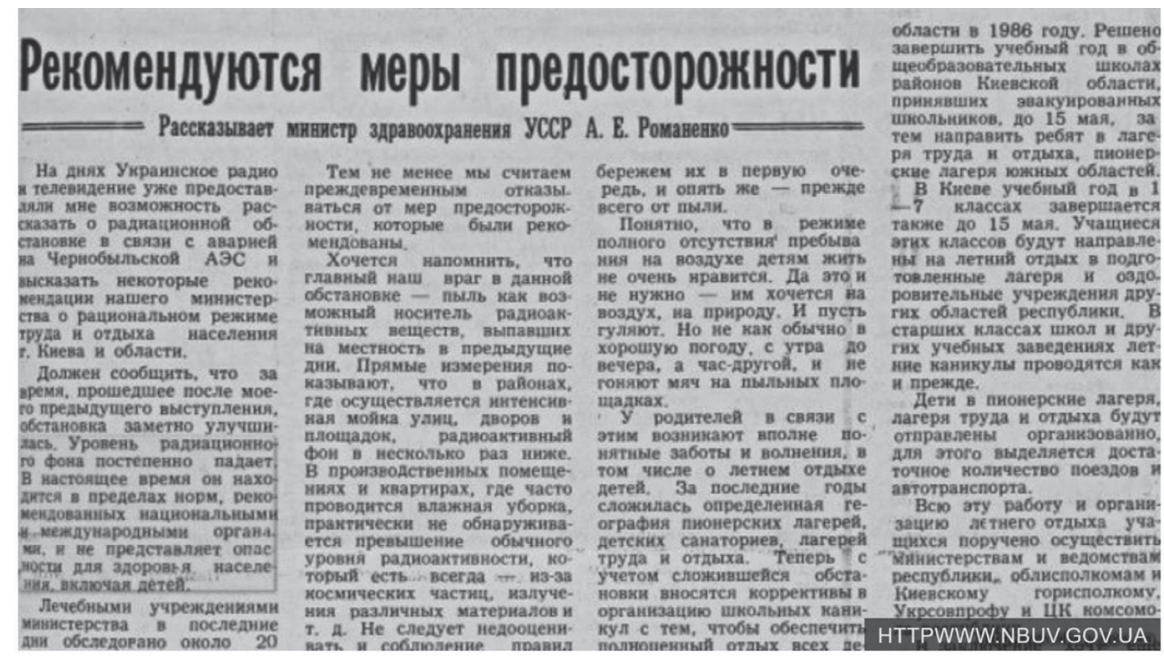

Źródło: [Zanuda, 2016a] 
Wykres 4.

Pomiary promieniowania radiacyjnego w Kijowie 30.04-02.05.1986 roku

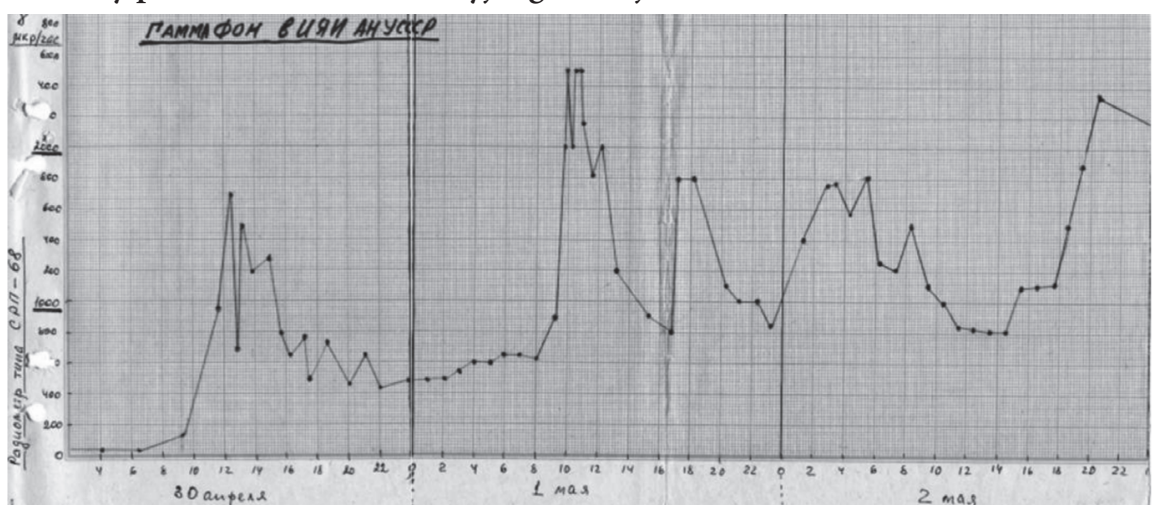

Źródło: Archiwum Państwowe Służby Bezpieczeństwa Ukrainy [Hrafik vymiru radiatsiyi... 1986]

Ważne miejsce w prasie radzieckiej zajmowały reportaże inscenizacyjne, opisujące codzienne życie oraz odpoczynek likwidatorów awarii [Zdjęcie 5].

W chwili gdy nie można było już w pełni zaprzeczać awarii, władza radziecka poprzez środki masowej informacji zaczęła tworzyć mit o nieszkodliwości, a nawet o korzystnym wpływie małych dawek radiacji. Po awarii prasa często pisała o pozytywnym wpływie podwyższonej radiacji na zdrowie i życie. Ilustrowano to przykładami z życia mieszkańców górskich rejonów Kaukazu i Tybetu, gdzie zanotowano najdłuższą średnią wieku przy podwyższonej radiacji. Ten mit miał wielkie znaczenie dla ludzi starszych, dla których taka informacja była istotną podstawą, aby odmawiać wyjazdu $\mathrm{z}$ terenów skażonych lub na nie wracać [Omelchenko, 2002]. 
Zdjęcie 5.

Gazeta „Weczirnij Kyjiw”, 19 maja 1986 roku, nr 115(12730)

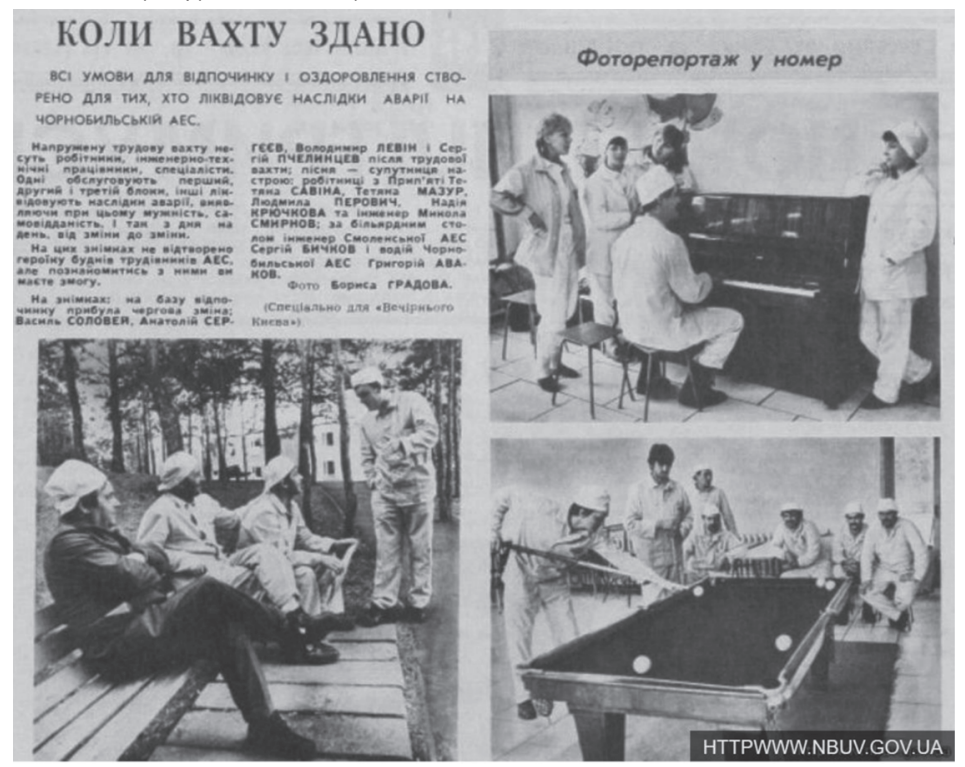

Źródło: [Zanuda, 2016a]

\section{ZAPOBIEGANIE PRZEDOSTAWANIU SIĘ INFORMACJI O KATASTROFIE POZA GRANICE ZSRR}

Wraz z rozpowszechnieniem się na świecie informacji o awarii w Czarnobylskiej Elektrowni Jądrowej wzrastała ilość natarczywych żądań oraz oficjalnych i nieoficjalnych prób dochodzenia prawdy ze strony pracowników przedstawicielstw dyplomatycznych oraz korespondentów i innych cudzoziemców. Zatajanie informacji w takich warunkach zmusiło ZSRR do podjęcia szczególnych wysiłków. Podczas gdy wypracowywane latami metody wpływu na obywateli radzieckich były bezpośrednie, to oddziaływanie na cudzoziemców wymagało specjalnych środków.

Po przeanalizowaniu niektórych z odtajnionych przez Służbę Bezpieczeństwa Ukrainy dokumentów [Chornobyl's'ka trahediya...] można wyróżnić następujące metody działań KGB, zmierzające do ograniczenia dostępu cudzoziemców do informacji o awarii w CzEJ [Tabela 2]. 
Tabela 1.

Metody działań KGB w zakresie ograniczenia dostępu cudzoziemców do informacji o awarii w CzEJ

\begin{tabular}{|c|c|c|}
\hline $\begin{array}{c}\text { Działania } \\
\text { cudzoziemców }\end{array}$ & Działania KGB & Przykłady udokumentowane \\
\hline 1 & 2 & 3 \\
\hline \multirow[t]{3}{*}{$\begin{array}{l}\text { Oficjalne } \\
\text { pytania ze strony } \\
\text { zagranicznych } \\
\text { ambasad } \\
\text { oraz środków } \\
\text { masowego } \\
\text { przekazu }\end{array}$} & $\begin{array}{l}\text { Udzielanie „poprawnych” } \\
\text { informacji za } \\
\text { pośrednictwem } \\
\text { przedstawicielstw } \\
\text { zagranicznych, na które } \\
\text { ZSRR miał wpływ }\end{array}$ & $\begin{array}{l}\text { „Szereg ziomkostw (Liban, Syria itp.) wysłało oficjal- } \\
\text { ne odpowiedzi do ojczyzny o tym, że rozpowszech- } \\
\text { niane na Zachodzie pogłoski są bezpodstawne i wy- } \\
\text { paczają rzeczywistą sytuację w Kijowie i obwodzie" } \\
\text { [Spravka ob informatsii iz mest evakuatsii..., 1986, } \\
\text { arkusz tomu 138, strona dokumentu 3]. } \\
\text { „W dniu } 8 \text { maja odnotowano połączenie telefoniczne } \\
\text { Z japońskiej telewizji do Kijowskiego Uniwersytetu } \\
\text { Państwowego... Cudzoziemcy otrzymali odpowiedź } \\
\text { o tym, że sytuacja odpowiada informacjom opubliko- } \\
\text { wanym w prasie” [Spravka ob informatsii iz mest eva- } \\
\text { kuatsii..., 1986, arkusz tomu 138, strona dokumentu 3] }\end{array}$ \\
\hline & $\begin{array}{c}\text { Przeszkadzanie } \\
\text { w fizycznym dostępie do } \\
\text { źródeł informacji }\end{array}$ & $\begin{array}{l}\text { „W Kijowie przebywa } 16 \text { korespondentów zagra- } \\
\text { nicznych. Zapobieżono podjętym przez korespon- } \\
\text { dentów z Anglii, Francji i Szwecji próbom zebrania } \\
\text { tendencyjnych informacji na dworcu kolejowym } \\
\text { m. Kijowa poprzez wprowadzenie do akcji człon- } \\
\text { ków drużyn specjalnych ukraińskiego KGB, którzy } \\
\text { skupili uwagę cudzoziemców na sobie” [Spravka } \\
\text { ob informatsii iz mest evakuatsii..., 1986, arkusz } \\
\text { tomu 137, strona dokumentu 2] }\end{array}$ \\
\hline & $\begin{array}{l}\text { Kompleksowe operacje } \\
\text { specjalne }\end{array}$ & $\begin{array}{l}\text { „2-3 czerwca } 1986 \text { roku w m. Kijowie przebywal } \\
\text { korespondent czasopisma »Newsweek« Strasser Ste- } \\
\text { ven, ur. } 1946 \text { roku, który przybył z celem zdobycia } \\
\text { materiałów o skutkach awarii w Czarnobylskiej EJ. } \\
\text { Zgodnie z wytycznymi Centrum, wspólnie z } 2 \text { Z KGB } \\
\text { USRR w stosunku do Amerykanina zastosowano } \\
\text { kompleks metod czekistowskich celem niedopusz- } \\
\text { czenia do zdobycia informacji o charakterze oszczer- } \\
\text { czym, paraliżowania jego działań i ograniczenia ak- } \\
\text { tywności. Do działań skierowano } 8 \text { emerytowanych } \\
\text { oficerów KGB, } 19 \text { członków drużyn specjalnych, } \\
\text { w tym } 7 \text { źródeł, którzy realizowali taktykę ofensyw- } \\
\text { nego prowadzenia rozmów z korespondentem. Z po- } \\
\text { zycji oficjalnych w rozpracowywaniu Strassera wyko- } \\
\text { rzystano agentkę „Rota”. W rezultacie zastosowanych } \\
\text { działań cudzoziemiec od obywateli radzieckich nie } \\
\text { otrzymał tendencyjnych informacji. Udało się ogra- } \\
\text { niczyć kontakty Strassera, skierować je na nasze źró- } \\
\text { dła” [Dovidka shchodo perebuvannya..., 1986] }\end{array}$ \\
\hline
\end{tabular}




\begin{tabular}{|c|c|c|}
\hline 1 & 2 & 3 \\
\hline $\begin{array}{l}\text { Próby wyjazdu } \\
\text { z ZSRR } \\
\text { podejmowane } \\
\text { przez studentów } \\
\text { zagranicznych }\end{array}$ & $\begin{array}{l}\text { Zamaskowana pod } \\
\text { różnymi pozorami } \\
\text { odmowa sporządzenia } \\
\text { dokumentów do } \\
\text { wyjazdu do ojczyzny } \\
\text { i przeprowadzenie } \\
\text { rozmów „przekonujących”. }\end{array}$ & $\begin{array}{l}\text { „(... ) z powodu odmowy sporządzenia dokumen- } \\
\text { tów do wyjazdu do ojczyzny studentowi wydziału } \\
\text { przygotowawczego Kijowskiego Uniwersytetu Pań- } \\
\text { stwowego Pierre’a Conrada (Mauretania) (...) po } \\
\text { przeprowadzonej rozmowie z wyjazdu zrezygnował” } \\
\text { [Spravka ob informatsii iz mest evakuatsii... 1986, ar- } \\
\text { kusz tomu 137]. }\end{array}$ \\
\hline \multirow{2}{*}{$\begin{array}{l}\text { Podejmowane } \\
\text { przez } \\
\text { obcokrajowców } \\
\text { próby } \\
\text { przekazywania } \\
\text { informacji } \\
\text { otrzymanych } \\
\text { ze źródeł } \\
\text { zagranicznych }\end{array}$} & $\begin{array}{c}\text { Przeprowadzenie rozmów } \\
\text { „przekonujących” }\end{array}$ & $\begin{array}{l}\text { „Doktorant instytutu wychowania fizycznego Sta } \\
\text { Mohamed, ur. } 1959 \mathrm{r} \text {. (Tunezja) (...) rozpowszechniał } \\
\text { domysły o awarii w CzEJ, zalecał natychmiastowy } \\
\text { wyjazd z ZSRR (...) ograniczony przez agenturę i ad- } \\
\text { ministrację uczelni” [Spravka ob informatsii iz mest } \\
\text { evakuatsii ..., 1986, arkusz tomu 138, strona doku- } \\
\text { mentu 3]. }\end{array}$ \\
\hline & $\begin{array}{c}\text { Przymusowy wyjazd } \\
\text { z ZSRR }\end{array}$ & $\begin{array}{l}\text { „(...) obywatelka Polskiej Rzeczpospolitej Ludowej } \\
\text { (...) rozsiewa paniczne pogłoski (...) Informacja zo- } \\
\text { stała przekazana do wiadomości oficera bezpieczeń- } \\
\text { stwa MSW PRL Potockiego, który podjał decyzje } \\
\text { o opuszczeniu ZSRR przez Tomasinę Elę" [Spravka } \\
\text { ob informatsii iz mest evakuatsii..., 1986, arkusz } \\
\text { tomu 138, strona dokumentu 3] }\end{array}$ \\
\hline
\end{tabular}

Źródło: opracowanie własne na podstawie dokumentów Archiwum Państwowego Służby Bezpieczeństwa Ukrainy

Warto również zwrócić uwagę na to, że wg stanu na 8 maja 1986 roku w Kijowie było zarejestrowanych 8968 studentów zagranicznych. Spośród nich po świętach majowych do Kijowa nie powróciło 307 osób, po katastrofie poza granice Kijowa wyjechało zaś 48 osób [Spravka ob informatsii iz mest evakuatsii... 1986, arkusz tomu 138, strona dokumentu 3]. Zaprezentowana Tabela 2 również na pewnych przykładach ilustruje, w jaki sposób „przekonywano” studentów zagranicznych. Następnie w prasie pojawiały się informacje podobne do tej: „(...) w Kijowie studiuje 8 tysięcy studentów zagranicznych. Spośród nich miasto opuściło 8 osób. Fakt ten świadczy o normalnej sytuacji panującej dziś w Kijowie” [Gazeta „Izvestiya”..., 1986].

KGB dysponował więc całym kompleksem wypracowanych działań skierowanych na ograniczenie dostępu cudzoziemców do informacji o awarii w CzEJ. W odróżnieniu od Służby Bezpieczeństwa Ukrainy, służby specjal- 
ne Federacji Rosyjskiej dotąd nie odtajniły dokumentów związanych z katastrofą - dlatego całościowy obraz działań KGB w stosunku do własnych obywateli oraz do cudzoziemców można sobie tylko wyobrazić. Wiadomo jedynie, że organy KGB stale doskonaliły swe metody i techniki wpływu. Zwłaszcza Zarządzenie przewodniczącego komitetu bezpieczeństwa państwowego (KGB) ZSRR „O środkach wzmagania działań kontrwywiadowczych na obiektach energetyki atomowej w związku z awarią w Czarnobylskiej EJ” zawiera wiele wyraźnych wskazówek dotyczących usprawnienia pracy Komitetu (KGB): „4) (...) ostrzej reagować na sygnały o działaniach cudzoziemców i ich kontaktach z obywatelami radzieckimi celem zdobycia informacji o rozmiarach i skutkach awarii w Czarnobylskiej EJ(...); 6) (...) aktywizować pracę rezydentur celem wykrycia planów i zamysłów służb specjalnych przeciwnika odnośnie do energetyki atomowej ZSRR. (...) Wytrwale przeciwdziałać podejmowanym przez służby specjalne przeciwnika próbom dyskredytowania rozwoju energetyki krajowej i współpracy ZSRR z innymi krajami w tej sferze" [Prikaz predsedatelya komiteta... 1986].

\section{Mitologizacje WSPóŁCZeSne}

Współczesna propaganda rosyjska usiłuje przedstawić Ukrainę jako miejsce, w którym życie ludzkie jest zewsząd zagrożone. Celem fejkowych wiadomości o katastrofach ekologicznych, do których jakoby dochodzi, jest wykreowanie obrazu władz ukraińskich jako lekceważących życie i zdrowie własnych obywateli. Przy czym na uwagę zasługuje fakt, że w czasach radzieckich czarnobylska EJ była bezpośrednio podporządkowana władzom w Moskwie (a nie miejscowym władzom ukraińskim), a więc logiczne jest, że odpowiedzialność za awarię na poziomie kierowniczym musi spoczywać na komunistycznej „moskiewskiej wierchuszce”.

Dziś jednak rosyjskie środki masowego przekazu tradycyjnie milczą na temat roli Moskwy w tragedii. Sięgają do pamięci i emocji związanych z radziecką próbą mitologizacji wydarzeń w CzEA, lecz już przenicowują temat - teraz przeciwnie - wszystko, co odbywa się na Ukrainie i jest związane z Czarnobylem, jest zagrożeniem dla życia. Rosja w mediach rosyjskich jawi się jako bezinteresowny wybawca Ukrainy, a prozachodnie ukraińskie władze w sposób przestępczy odmawiają przyjęcia pomocy z jej strony. 
Na przykład 22 kwietnia 2016 roku kremlowscy propagandziści ogłosili, że: „Ukraina szykuje światu nowy Czarnobyl” [Na poroge katastrofy..., 2016]. Poinformowano, że Ukraina rzekomo wciąż odrzuca wszystko co rosyjskie, nawet na własną szkodę, a jednym z tego dowodów jest przejście z rosyjskiego paliwa jądrowego na paliwo amerykańsko-japońskiej kompanii „Westinghouse”. Decyzja ta jest rzekomo bardzo niebezpieczna, gdyż zachodnie paliwo nie nadaje się do radzieckich reaktorów. Zatem rosyjskie mass media robiły wszystko, by zasiać wśród ludności strach przed „nowym Czarnobylem” - normalna dla nich taktyka apelowania do silnych emocji, które przesłaniają racjonalność jakiegokolwiek projektu. Oprócz celu ogólnego, jakim jest dyskredytacja polityki ekologicznej ukraińskich władz, kremlowscy propagandziści mają dość konkretny cel - zmusić ukraińskie władze do rezygnacji z przejścia na paliwo jądrowe amerykańskiej kompanii „Westinghouse” [„Druhyy Chornobyl”, ... 2018]. Takie i podobne fejki rosyjskie mass media produkują w wielkich ilościach.

\section{ODTAJNIANIE INFORMACJI}

Za przyczynę oficjalnego potwierdzenia faktu awarii w Czarnobylu można uznać presję międzynarodową na ZSRR, dopiero bowiem po uporczywych żądaniach i bezpośrednich groźbach zwrócenia się przez Szwecję z oficjalnym zapytaniem do International Atomic Energy Agency (IAEA) [25 years after Chernobyl..., 2011] władze radzieckie zdawkowo, „na siłę” zaczęły oficjalnie przyznawać, że doszło do awarii.

Dopiero wraz z upadkiem systemu radzieckiego pojawiła się możliwość całościowego i zgodnego z prawdą przedstawienia wydarzeń związanych $\mathrm{z}$ awarią w Czarnobylskiej Elektrowni Atomowej. Wkrótce po uzyskaniu przez Ukrainę niezależności, w ust. 3 art. 13 Ustawy Ukrainy „O informacji” zaznaczono, że dane o stanie środowiska naturalnego nie mogą być kwalifikowane jako informacje o ograniczonym dostępie [Zakon Ukrainy „Pro informatsiyu”, 1992]. Rozpoczęło się również stopniowe odtajnianie przez Ukrainę archiwów radzieckich, zwłaszcza związanych z katastrofą w Czarnobylu. Jednakże w pełni archiwa stały się dostępne dopiero po wejściu w życie Ustawy Ukrainy „O dostępie do archiwów organów represji komunistycznego reżimu totalitarnego z lat 1917-1991” [Zakon Ukrainy 
„Pro dostup do arkhiviv..., 2015]. Z niektórymi dokumentami w wersji elektronicznej można zapoznać się na stronie internetowej Archiwum elektronicznego ukraińskiego ruchu wyzwoleńczego w rozdziale „Tragedia Czarnobylska - zbrodnia władz radzieckich. Dokumenty z Archiwum SBU" [Chornobyl's'ka trahediya...].

Awaria spowodowała wzrost nieufności obywateli Ukraińskiej SRR do istniejącego systemu. Historyk Natalija Baraniwśka uważa, że chociaż wiele osób przez całe lata było niezadowolonych z reżimu radzieckiego, to właśnie katastrofa jądrowa i jej skutki, a zwłaszcza nieudane próby kierownictwa ZSRR zatajenia i umniejszenia rozmiarów tragedii zaktywizowały świadomość i aktywność polityczną obywateli [Vorozhko 2011]. Taką samą opinię wyraziła również ówczesna Przewodnicząca Prezydium Rady Najwyższej Ukraińskiej SRR Walentyna Szewczenko: „Nie powiedziałabym, że awaria jest bezpośrednio związana $z$ rozpadem ZSRR, nie, on (rozpad) już wisiał w powietrzu. Lecz Czarnobyl rzeczywiście mógł być tą kroplą, która przepełniła czarę goryczy" [Shevchenko, 2011].

Skutki awarii w Czarnobylskiej EJ są dziś badane na poziomie międzynarodowym - zarówno jeśli chodzi o skażenie promieniotwórcze środowiska naturalnego, jak i jego wpływu na ludzkie zdrowie [1986-2011: L'accident de Tchernobyl et ses conséquences...; The Chernobyl accident... 2012; 1986-2016: Tchernobyl, 30 ans après; Accident de Tchernobyl]. Według stanu na kwiecień 2011 roku, na podstawie danych Ministerstwa Zdrowia Ukrainy [Yak trahediya... 2011], odsetek likwidatorów uznanych za zdrowych wynosił zaledwie 4,37\%. Naukowo dowiedziono, że „długotrwałe narażenie na promieniowanie o małym natężeniu doprowadza do zmian w układzie krwiotwórczym, które zwiększają ryzyko powstania chorób mieloproliferacyjnych. Skutkiem niedoborów odporności wywołanych promieniowaniem są choroby autoimmunologiczne i zespół przewlekłego zmęczenia. Popromienne uszkodzenia narządów wewnątrzwydzielniczych prowadzą do układowych zaburzeń funkcjonowania organizmu i wielopatologii. Stwierdzono wysoką promienioczułość ośrodkowego układu nerwowego. Długotrwałe genotoksyczne oddziaływanie radiacyjne zagraża stabilności genomu" [Drozd 2013]. 


\section{WNIOSKI}

Prędzej czy później nadchodzi czas na zdemaskowanie mitu. Mit o nieszkodliwości (niskiej szkodliwości, a nawet korzystnym wpływie) podwyższonego tła promieniotwórczego wskutek awarii w Czarnobylskiej EJ upadł dosyć szybko. Mit okazał się kruchy - przebiegu reakcji chemicznych nie można było podporządkować wytycznym władz radzieckich i zastraszyć metodami KGB, a skutki awarii były zbyt oczywiste, by je całkowicie pominąć milczeniem. Główną przyczyną niepowodzenia w budowaniu radzieckiego mitu o nieszkodliwości promieniowania był rozgłos międzynarodowy.

Wszelkie dostępne środki konstruowania rzeczywistości alternatywnej (mitologizacji), praktykowane przez KGB - zatajanie prawdy; niszczenie dokumentów i dowodów rzeczowych; zastraszanie; blokowanie dostępu do źródeł wiarygodnej informacji; tworzenie "prawdy” alternatywnej; rozpowszechnianie jej w mediach - w przypadku awarii w Czarnobylskiej EJ 26 kwietnia 1986 roku zostały przez władze radzieckie zastosowane. Oprócz tego analiza skutków wielu radzieckich prób i awarii jądrowych prowadzi do wniosku, że gdyby wiatr nie zniósł pyłu radioaktywnego poza granice ZSRR i nie doszło do silnej presji międzynarodowej z żądaniami wyjaśnień - awaria w Czarnobylskiej EJ byłaby tak samo zatajona i zmitologizowana jak wiele innych radzieckich incydentów jądrowych, które stały się polami doświadczalnymi do obserwacji skutków radiacji.

Próba mitologizacji awarii w Czarnobylskiej EJ jest tylko jedną z wielu w radzieckiej rzeczywistości alternatywnej, która zasługuje na odrębne gruntowne badania.

\section{Dokumenty Sektorowego Archiwum Państwowego Służby Bezpieczeństwa Ukrainy}

Hrafik vymiru radiatsiyi v m. Kyiv na 1-e travnya $1986 r$. [Radiation level chart in Kyiv on the $1^{\text {st }}$ of May, 1986]. Kyiv: Institute of Nuclear Research of National Academy of Sciences of Ukrainian Soviet Republic. Sectoral State Archive of the Security Services of Ukraine, Fund 65. Case 1, Volume 34. Retrieved from: http://avr.org. ua/index.php/viewDoc/24448/(in Russian).

Dovidka shchodo perebuvannya v Kyivi korespondenta Steven Strasser i doktora Geyl $z$ USA vid 04.06.1986. [Information on staying of Steven Strasser and Dr. Geyl in Kyiv of 04.06.1986]. KGB of Ukrainian SSR. Sectoral State Archive of the Security 
Services of Ukraine, Fund 11, Case 992, Volume 29, Sheet 178. Retrieved from: http://avr.org.ua/index.php/viewDoc/24470/ (in Russian).

Informatsionnoye soobshcheniye za 25, 26 i 27 aprelya 1986 goda „O vzryve na ChAES”. [Informative message of $25^{\text {th }}, 26^{\text {th }}$ and $27^{\text {th }}$ April 1986 "About Explosion at Chornobyl Nuclear Power Plant"]. (28.04.1986). KGB USSR. Sectoral State Archive of the Security Services of Ukraine, Fund 16, Case 13, Sheet 56, Page 4. Retrieved from: http://www.memorial.kiev.ua/zhurnal/pdf/01_2001/023.pdf (in Russian).

Perechen' svedeniy, podlezhashchikh zasekrechivaniyu po voprosam, svyazannym s avariyey na bloke No 4 of Chornobyl Nuclear Power Plant. [List of Data on Issues Related to the Catastrophe at the $4^{\text {th }}$ block of the Chornobyl NPS Supposed to be Suppressed]. (08.07.1986). KGB USSR. Sectoral State Archive of the Security Services of Ukraine, Fund 11, Case 992, Volume 33, Sheet 182-184. Retrieved from: http:// avr.org.ua/index.php/viewDoc/24475/ (in Russian).

Prikaz predsedatelya komiteta gosudarstvennoy bezopasnosti USSR „O merakh po usileniyu kontrrazvedyvatel'noy raboty na ob'yektakh atomnoy energetiki $v$ svyazi s avariyey na Chornobylskoj AES" No 0515 ot 30.08.1986. [The Chairman of the USSR State Security Committee Order „About Measures of Counterintelligence Work Reinforcement at Nuclear Power Units due to Catastrophe at Chornobyl NPS" No 0515 of 30.08.1986]. Moscow: KGB USSR. Sectoral State Archive of the Security Services of Ukraine, Fund 9. Case 34. Sheet 88-89, Page 6-7. Retrieved from: http://avr.org. ua/index.php/viewDoc/24451/ (in Russian).

Spravka o radiatsionnoy obstanovke na 3 i 4 energoblokakh ChAES. [Report on Radiation Situation at the 3rd and 4th ChNPP Units]. 27.04.1986. Sectoral State Archive of the Security Services of Ukraine. Fund 11, Case 992, Volume 29, Sheet 101. Retrieved from: http://avr.org.ua/index.php/viewDoc/24466/ (in Russian).

Spravka ob informatsii iz mest evakuatsii ot 08.05.1986. [Report on Data From Places of Evacuation of 08.05.1986]. Sectoral State Archive of the Security Services of Ukraine, Fund 11, Case 992, Volume 29. Retrieved from: http://avr.org.ua/index. $\mathrm{php/viewDoc/24469/(in} \mathrm{Russian).}$

\section{Akty prawne}

Zakon Ukrainy „Pro dostup do arkhiviv represyvnykh orhaniv komunistychnoho totalitarnoho rezhymu 1917-1991 rokiv" No 316-VIII vid 09.04.2015. [Law of Ukraine „On Access to Archives of Repressive Bodies of the Communist Totalitarian Regime of 1917-1991" No 316-VIII of 09.04.2015]. Retrieved from: http://zakon.rada.gov.ua/ laws/show/316-19 (in Ukrainian). 
Zakon Ukrainy "Pro informatsiyu” No 2657-XII vid 02.10 .1992 u redaktsii vid 01.01.2017. [Law of Ukraine „On Information” No 2657-XII of 02.10.1992, version of 01.01.2017]. Retrieved from: http://zakon.rada.gov.ua/laws/show/2657-12 (in Ukrainian).

\section{Bibliografia}

Drozd, I.P. (2013). Khronichnyy vplyv ionizuyuchoyi radiatsiyi na orhanizm tvaryn $i$ lyudyny. [Chronic Effects of Ionizing Radiation on the Organism of Animals and Humans]. Nuclear Physics and Atomic Energy, ISSN 1818-331X, 2013, T. 14, № 1, C. 42-50 (in Ukrainian).

„Druhyy Chornobyl” v Ukraini cherez amerykans'ke yaderne palyvo. (2018). [in] White Book of Special Information Operations against Ukraine 2014-2018. Ed.: D.Yu. Zolotuchin. Ministry of Information Policy of Ukraine. Kyiv: „Mega-press groups”, 384 p. ISBN 9789669773227. Retrieved from: http://mip.gov.ua/files/pdf/white_ book_2018_mip.pdf?fbclid=IwAR2ECD6ji9A5EW4BKYisQ0r9kfECnSD0_qXgcYGlorGZ2FvaQ_alDTAAPJs (in Ukrainian).

Sokolova, S. (2017). The Russian-language Wikipedia as a Measure of Society Political Mythologization. Journal of Modern Science, 33(2), 147-176. ISSN 1734-2031.

Sokolova, S. (2018). Violations of Comparative Method Application within Internet Discussions of Fiction. Journal of Modern Science, 38(3), 87-109. ISSN 1734-2031. https://doi.org/10.13166/jms/99214.

\section{Netografia}

1986-2011: Laccident de Tchernobyl et ses conséquences pour l'environnement et la santé. Les leçons de Tchernobyl. IRSN (Institut de Radioprotection et de Sûreté Nucléaire, France). Retrieved from: https://www.irsn.fr/FR/connaissances/Installations_ nucleaires/Les-accidents-nucleaires/accident-tchernobyl-1986/consequences-homme-environnement/Pages/3-Le_panache_radioactif.aspx\#.W68zzWgzY2w

1986-2016: Tchernobyl, 30 ans après. Les leçons de Tchernobyl. IRSN (Institut de Radioprotection et de Sûreté Nucléaire, France). Retrieved from: https://www. irsn.fr/FR/connaissances/Installations_nucleaires/Les-accidents-nucleaires/ accident-tchernobyl-1986/2016-Tchernobyl-30ans-apres/Pages/0-Tchernobyl-2016-30ans-apres-Sommaire.aspx\#.W69AGmgzY2x

25 years after Chernobyl, how Sweden found out. (2011). Radio Sweden. Published April 22, 2011. Retrieved from: https://sverigesradio.se/sida/artikel.aspx?programid=2054\&artikel $=4468603$ 
Accident de Tchernobyl: déplacement du nuage radioactif au dessus de l'Europe entre le 26 avril et le 10 mai 1986. Carte animée du nuage radioactif. Les leçons de Tchernobyl. IRSN (Institut de Radioprotection et de Sûreté Nucléaire, France). Retrieved from: https://www.irsn.fr/FR/popup/Pages/tchernobyl_video_nuage.aspx

Chernobyl haunts engineer who alerted world. (1996). CNN Interactive World News. Cable News Network, Inc. 26 April 1996. Retrieved from: http://edition.cnn.com/ WORLD/9604/26/chernobyl/230pm/index2.html.

The Chernobyl accident: UNSCEAR's assessments of the radiation effects. United Nations Scientific Committee on the Effects of Atomic Radiation. 16 July 2012. Retrieved from: http://www.unscear.org/unscear/en/chernobyl.html.

The wasteful truth about the Soviet nuclear disaster. New Scientist, 10.01.1980. Retrieved from: https://books.google.ru/books?id=UzTvnbODqHgC\&pg=PA61\&hl $=\mathrm{uk} \# \mathrm{v}=$ onepage $\& \mathrm{q} \& \mathrm{f}=$ false.

Tissen, D. (2005). Nuclear Test in Totskoye in 1954. Neu Samara. Last modified: January 22, 2005. Retrieved from: http://www.neu-samara.de/index.php?artike$\mathrm{l}=9$ \&sprache $=\mathrm{en}$.

Tsar Bomba. (2014). Atomic Heritage Foundation. Publication August 8, 2014. Retrieved from: https://www.atomicheritage.org/history/tsar-bomba.

Vorozhko, T. (2011). Chornobil' prishvidshiv rozpad USSR, vvazhayut' istoriki. [Chernobyl Accelerated the Collapse of the USSR, Historians Say]. Website: VOANews. com. Publication 26.04.2011. Retrieved from: https://ukrainian.voanews.com/a/ chornobyl-ussr-04-26-2011-120721109/240298.html (in Ukrainian).

Gazeta „Izvestiya” [„Izvestia” newspaper], 10.05.1986. Chornobyl'skaya byl’. [Chornobyl fact]. Personal website: AVAndrzheyevskyy. Retrieved from: http://avandrzheyevskyy.narod.ru/index/0-16 (in Russian).

Zanuda, A. (2016a). Chornobyl' $i$ „hlasnist”: shcho pysaly radyans'ki hazety pro avariyu. [Chornobyl and „Glasnost”(publicity): What Soviet Newspapers Wrote about the Catastrophe]. BBC Ukraine. 26.04.2016. Retrieved from: https://www.bbc.com/ ukrainian/society/2016/04/160421_chornobyl_pressa_az (in Ukrainian).

Zanuda, A. (2016b). Chornobyl'-30: spohady, zasvidcheni arkhivamy KGB. [Chornobyl-30: memories evidenced by KGB archives]. BBC Ukraine. 25.04.2016. Retrieved from: https://www.bbc.com/ukrainian/society/2016/04/160419_chornobyl_kgb_ archives_memories_az (in Ukrainian).

Zghurskyi, V. (2013). Pravdu pro chornobyl's'ku avariyu u pershi dni znaly lyshe try osoby: Gorbachev, Ryzhkov i ya. Interv'yu 2013 roku v 3-kh chastynakh. Chastyna 
II. [Only three persons knew about Chornobyl catastrophe for the first days: Gorbachev Ryzhkov and me. Interview of 2013 in three parts. Part II]. Internet edition „HORDON”: „Visiting Dmitri Hordon” TV program. Publication 27.10.2016. Retrieved from: https://gordonua.com/ukr/interview/tv_full/valentin-zgurskij-pravdu-pro-chornobilskoji-avariji-v-pershi-dni-znali-lishe-tri-osobi-gorbachovrizhkov-156317.html (in Ukrainian).

Ispytaniye Tsar'-bomby (ofitsial'naya khronika). [Tsar-Bomb test]. Publication 01.04.2012. Retrieved from: https://www.youtube.com/watch?v=lfi0zYoqCY0 (in Russian).

Miller, I. (2016). Sokunstkamerniki ponevole. [Cabinet of Curiousity Co-Members against One's Will]. „Express K” (internet-version of the newspaper). Publication 06.09.2016. Retrieved from: https://express-k.kz/news/zhizn/sokunstkamerniki_ponevole-82464 (in Russian).

Na poroge katastrofy: zachem Ukraina gotovit miru vtoroy Chornobyl'. Telekanal „Zvezda”. 22.04.2016. Retrieved from: https://tvzvezda.ru/news/vstrane_i_mire/ content/-201604220753pjdd.htm (in Russian).

Omelchenko, O. (2002). Chotyry chornobyl's'ki mify. Chomu nas nichomu ne vchat' ekolohichni katastrofy? [Four Chornobyl Myths. Why don't Ecological Catastrophes Teach Us Anything?]. „Den” newspaper, 17 December, 2002., No 232. Retrieved from: https://day.kyiv.ua/uk/article/cuspilstvo/chotiri-chornobilski-mifi (in Ukrainian).

Stattya 62 KK USSR „Antyradyans'ka ahitatsiya i propahanda”, vvedena $v$ diyu 01.01.1961. (Tekst statti ta komentar do statti). [Article 62 of The Ukrainian SSR Criminal Code "Anti-soviet agitation and propaganda”, enterd into force on 01.01.1961 (the article code and comments to the article)]. Virtual Museum Dissident Movement in Ukraine. Retrieved from: http://archive.khpg.org/index.php?id=1162803885 (in Ukrainian).

Tolstikov, V.S. (2007). Radiatsionnaya avariya 1957 goda na Yuzhnom Urale: pravda i domysly. [Radiation Catastrophe of 1957 in Southern Ural: truth or conjectures]. Southern Ural Nature Protection of the: regional ecological almanac. Chelyabinsk, c. 19-23. Retrieved from: http://www.libozersk.ru/pbd/Mayak60/link/206.htm (in Russian).

Chornobyl's'ka trahediya - zlochyn radyans'koyi vlady. Dokumenty Arkhivu SBU. [Chornobyl Tragedy - the crime of the soviet power. Documents of Security Service of Ukraine archive]. Electronic archive of Ukrainian liberating movement. Retrieved 20.09.2018 from: http://avr.org.ua/index.php/ROZDILY_RES?idUpCat=867 (in Ukrainian). 
Shevchenko, B. (2011). „Chornobyl' dlya mene - yak zhyva rana”. Interv'yu vzyala Lina Kushnir. ["Chorobyl is like a living wound for me", the interview was taken by Lina Kushnir]. „Ukraina moloda” newspaper. Publication 22.04.2011. Retrieved from: http://www.umoloda.kiev.ua/number/1871/369/66512/ (in Ukrainian).

Yak trahediya na ChAES vplynula na zdorov'ya ukrayintsiv? [How did the tragedy on ChNPP Affect the Health of Ukrainians?]. Press service of the Ministry of Health of Ukraine. Government portal: Official website. Publication 27.04.2011. Retrieved 20.09.2018 from: http://www.kmu.gov.ua/control/uk/publish/printable_article?art_id=244236505 (in Ukrainian).

\section{Wideografia}

Repetitsiya Apokalipsisa: Totskiy poligon. [Apocalypse's Rechearsal: Totsky Polygon]. Documentary film. Publication 12.01.2012. Retrieved from: https://www.youtube. $\mathrm{com} /$ watch? $\mathrm{v}=\mathrm{sdwl0DTcVHc} \&$ feature $=$ player_detailpage $\# \mathrm{t}=1772 \mathrm{~s}$ (in Russian).

Sekretnyy front: Chornobyl'ska katastrofa ta eksperymenty nad lyud'my. [Secret Forefront: Chornobyl Catastrophe and experiments on people]. Issue of 27.09.2017. ICTV TV Channel. YouTube. Retrieved from: https://www.youtube.com/wat$\mathrm{ch} ? \mathrm{v}=2 \mathrm{rd} 74 \mathrm{O} 24 \mathrm{WAQ}$ (in Ukrainian).

Soobshcheniye programmy „Vremya” o Chornobyle ot 28.04.1986. [TV Program's „Vremya" message about Chornobyl of 28.04.1986]. YouTube. Publication 25.04.2011. Retrieved from: https://www.youtube.com/watch?v=VG6eIuAfLoM (in Russian).

Chornobyl': vystupleniye M.S. Gorbacheva 14.05.1986. [Chornobyl. Address of M.S. Gorbachev of 14.05.1986]. YouTube. Publication 12.01.2009. Retrieved from: https://www.youtube.com/watch?v=8Ro284RmXxE (in Russian). 